\title{
Remifentanil promotes osteoblastogenesis by upregulating Runx2/osterix expression in preosteoblastic $\mathrm{C} 2 \mathrm{C} 12$ cells
}

\author{
Ji-Young Yoon ${ }^{1}$, Tae-Sung Kim', Ji-Hye Ahn', Ji-Uk Yoon², Hyung-Joon Kim³, Eun-Jung Kim \\ 'Department of Dental Anesthesia and Pain Medicine, School of Dentistry, Pusan National University, Dental Research Institute, Yangsan, \\ Korea \\ ${ }^{2}$ Department of Anesthesia and Pain Medicine, School of Medicine, Pusan National University, Yangsan, Korea \\ ${ }^{3}$ Department of Oral Physiology, School of Dentistry, Pusan National University, Yangsan, Korea
}

\begin{abstract}
Background: The imbalance between osteoblasts and osteoclasts can lead to pathological conditions such as osteoporosis. It has been reported that opioid adversely affect the skeletal system, but it is inconsistent. Remifentanil is currently used as an adjuvant analgesic drug in general anesthesia and sedation. The aim of the present study was to investigate the effect of remifentanil on the osteoblast differentiation and mechanism involved in this effect.

Methods: The C2C12 cells (mouse pluripotent mesenchymal cell line) were used as preosteoblast. Osteoblastic differentiation potency was determined by alkaline phosphatase (ALP) staining. C2C12 cell migration by remifentanil was evaluated using Boyden chamber migration assay. The expression of Runx 2 and osterix was evaluated by RT-PCT and western blot analysis to investigate the mechanism involved in remifentanil-mediated osteoblast differentiation.

Results: ALP staining showed that remifentanil increased significantly osteoblast differentiation. In Boyden chamber migration assay, C2C12 cell migration was increased by remifentanil. RT-PCR and western blot analysis showed that the expression of Runx2 and osterix was upregulated by remifentanil.

Conclusions: We demonstrated that remifentanil increased osteoblast differentiation in vitro by upregulation of Runx 2 and osterix expression. Therefore, remifentanil has the potential for assisting with bone formation and bone healing.
\end{abstract}

Keywords: Osteoblasts; Osterix; Remifentanil; Runx2.

This is an Open Access article distributed under the terms of the Creative Commons Attribution Non-Commercial License (http://creativecommons.org/licenses/by-nc/4.0/) which permits unrestricted non-commercial use, distribution, and reproduction in any medium, provided the original work is properly cited.

\section{INTRODUCTION}

Bone is a specialized form of connective tissue that is constantly being remodeled. It is formed via three sequential processes: bone extracellular matrix is synthesized by osteoblasts (osteogenesis); bone is resorpted by osteoclast to form its shape in response to the physical environment (modeling); and the milieu is changed to adjust to the demands of the growth (remodeling) [1]. Each of these processes is mediated by the balance of bone-forming osteoblasts and boneresorbing osteoclasts [2]. A shift in this balance toward the activation of osteoclasts results in many clinical diseases, such as osteopenia and osteoporosis. Osteoporosis has been emerging as a global health concern that

Received: April 17, 2019 - Revised: April 21, 2019 - Accepted: April 23, 2019

Corresponding Author: Eun-Jung Kim, Department of Dental Anesthesia and Pain Medicine, School of Dentistry, Pusan National University, Dental Research Institute, Geumo-ro 20, Mulgeum-eup, Yangsan-si, Gyeongsangnam-do 50612, Korea

Tel: +82-55-360-5370 Fax: +82-55-360-5369 E-mail: kejdream84@naver.com

Copyright(c) 2019 Journal of Dental Anesthesia and Pain Medicine 
affects a wide range of populations, especially in old age [3]. Recently, osteoblast activity is considered a potential therapeutic target to control the osteopenic disease.

Osteoblasts are bone-forming cells that synthesize bone matrix, regulate mineralization, and eventually differentiate into osteocytes, or bone lining cells. They originate from mesenchymal stem cells and can differentiate into mature osteoblasts [4]. Mesenchymal stem cells give rise to preosteoblasts via activation of master transcriptional regulator, runt-related transcription factor 2 (Runx2) [5]. Thereafter, the growth and differentiation of osteoblast proceed in three stages with specific gene expression; the cells proliferate continuously and express collagen type I (COL1A1), TGF- $\beta$, fibronectin, and osteoponin (OPN); the extracellular matrix matures and expresses several extracellular matrix proteins including alkaline phosphatase (ALP) and COL1A1; and the matrix mineralizes and becomes enriched with osteocalcin, bone sialoprotein (BSP), and OPN. Subsequently, the mature osteoblasts with cuboidal shape is developed $[6,7]$.

Remifentanil is a synthetic opioid acting on $\mu$-opioid receptors, which is rapidly metabolized by nonspecific esterases in the plasma, giving it the characteristic of having very short onset and offset times [8]. Due to these properties, remifentanil has been used widely as an adjuvant analgesic drug during general anesthesia and sedation. The effect of remifentanil on osteoblasts has been investigated in previous studies. Yoon et al. [9] reported that remifentanil has a protective effect against oxidative stress on human osteoblasts. In another study, it was reported that pre-conditioning with remifentanil enhanced osteoblast maturation under hypoxia-reoxygenation conditions [10]. In the current study, we investigated the effect of remifentanil on osteoblast differentiation under normoxia state using $\mathrm{C} 2 \mathrm{C} 12$ cells. We also investigated the mechanism of remifentanilmediated osteoblast differentiation by analyzing osteoblastogenic genes expression.

\section{MATERIALS AND METHODS}

\section{Reagents}

Remifentanil was obtained from GlaxoSmithKline Pharmaceuticals (Rockville, MD, USA). The $\mathrm{C} 2 \mathrm{C} 12$ cells (mouse pluripotent mesenchymal cell line) were purchased from American Type Culture Collection (ATCC; Manassas, VA, USA). Leukocyte Alkaline Phosphatase Kit (for ALP staining) was purchased from Sigma-Aldrich (St. Louis, MO). Anti-Runx2 antibodies were purchased from MBL (Nagoya, Japan), anti-osterix antibodies were purchased from Santa Cruz Biotechnology, Inc. (Santa Cruz, CA). All other chemicals and reagents were purchased from Sigma-Aldrich.

\section{Cell culture and osteogenic differentiation}

The $\mathrm{C} 2 \mathrm{C} 12$ cells were maintained in Dulbecco's modified Eagle medium (DMEM; Gibco-BRL, Gaithersburg, MD, USA), containing 10\% fetal bovine serum (FBS) and $1 \%$ antibiotics $(50 \mathrm{U} / \mathrm{ml}$ of penicillin-G and $0.05 \mathrm{mg} / \mathrm{ml}$ of streptomycin) (Gibco-BRL), at $37^{\circ} \mathrm{C}$ in a humidified $5 \% \mathrm{CO}_{2}$ atmosphere. For the experiments, $\mathrm{C} 2 \mathrm{C} 12$ cells were exposed to indicated dose of remifentanil. We assigned the group received no chemical treatment as a control group. For osteogenic differentiation of $\mathrm{C} 2 \mathrm{C} 12$ cells, a mineralizing medium was used, which comprised of DMEM and $100 \mu \mathrm{g} / \mathrm{ml}$ bone morphogenic protein (BMP)-2. C2C12 cells processed with osteogenic differentiation were used as preosteoblasts. Media were changed every $48 \mathrm{~h}$.

\section{Cytotoxicity and cell proliferation assays}

The effects of remifentanil on cell viability and proliferation were measured using the well-established colorimetric 3-(4,5-dimethylthiazol)-2,5-diphenyltetrazolium bromide (MTT; Sigma-Aldrich) assay. In brief, the $\mathrm{C} 2 \mathrm{C} 12$ cells were plated in 96-well plates and treated with the indicated doses of remifentanil $(0,0.1,1,10$, and 100 $\mathrm{ng} / \mathrm{ml}$ ) for up to 3 days. At the end of the culture period, cells were incubated with fresh medium containing 0.5 
$\mathrm{mg} / \mathrm{ml}$ MTT solution for over $4 \mathrm{~h}$. After incubation, the formation of blue formazan product was measured using a microplate reader at a wavelength of $570 \mathrm{~nm}$.

\section{Alkaline phosphatase (ALP) staining}

The $\mathrm{C} 2 \mathrm{C} 12$ cells were seeded into 48 -well culture plates at a density of $2 \times 10^{4}$ cells/well and then incubated for $24 \mathrm{~h}$. Cells were treated with the indicated dose of remifentanil $(0,1$, and $10 \mathrm{ng} / \mathrm{ml})$ and $100 \mu \mathrm{g} / \mathrm{ml} \mathrm{BMP-2,}$ then cultured for an additional 24 and $72 \mathrm{~h}$. The mineralizing medium was replaced every $48 \mathrm{~h}$. To examine the ALP activity and quantitative analysis of ALP-positive area, ALP staining kit (86R-1KT, SigmaAldrich, St. Louis, MO, USA) was used according to the manufacturer's instructions. Sodium nitrate solution, 0.1 $\mathrm{ml}$, and FRV-alkaline solution, $0.1 \mathrm{ml}$, were mixed and incubated for $2 \mathrm{~min}$ at room temperature. The mixed solution was diluted with $4.7 \mathrm{ml}$ of double distilled water and supplemented with $0.1 \mathrm{ml}$ of naphthol AS-BI alkaline solution, resulting in an alkaline-dye mixture. The cultured cells were washed with cold phosphate buffered saline (PBS) and fixed with ALP fixing solution for 30 $\mathrm{s}$ at room temperature. After the fixation procedure, the cells were washed three times with distilled water. The alkaline-dye mixture was added to the culture plates at a quantity of $200 \mu 1 /$ well. The plate was wrapped with foil and incubated for 5 to $20 \mathrm{~min}$ at $37^{\circ} \mathrm{C}$ in the dark.

\section{Boyden chamber migration assay}

To examine the cell migration capacity by chemoattractant, we conducted Boyden chamber migration assay. The $\mathrm{C} 2 \mathrm{C} 12$ cells were suspended in DMEM medium at a concentration of $1 \times 10^{5}$ cells $/ 100 \mu \mathrm{l}$, and were added to the upper chamber of the transwell plates with $8 \mu \mathrm{m}$ porosity polycarbonate membrane. Remifentanil (10 and $50 \mathrm{ng} / \mathrm{ml}$ ) in DMEM medium was added to the lower chamber of each well as a chemoattractant. The $\mathrm{C} 2 \mathrm{C} 12$ cells that migrated through the filter onto the lower side were fixed by carefully immersing the filter into methanol for $1 \mathrm{~min}$. The cells were then stained with crystal violet and counted in three random microscopic fields of view per well. Each experiment was performed in duplicate and three separate experiments were performed in each group.

\section{Reverse transcriptase polymerase-chain reaction (RT-PCR) analysis}

Quantification of mRNA expression by PCR analysis was performed following a standard procedure. Total RNA was purified with TRIzol reagent (Invitrogen, CA, USA), and $1.5 \mu \mathrm{g}$ of each RNA sample was reversetranscribed using Superscript II (Invitrogen) according to the manufacturer's instructions. The primer sets used in the PCR were as follows; Runx2, 5'- CCG CAC GAC AAC CGC ACC AT-3' (forward) and 5'- TCA GCA CAT AGC CCA CAC CG-3' (reverse); OPN, 5'- CAG CTC AGA GGA GAA GAA GC -3' (forward) and 5'TGT AGG GAC GAT TGG AGT GA -3' (reverse); BSP, 5'- TTT GCG GAA ATC ACT CTG GG -3' (forward) and 5'- TAC GAA CAA ACA GGC AAC GA -3' (reverse); COL1A1, 5'- GGG CAA GAC AGT CAT CGA AT -3' (forward) and 5'-ATC ATA AGC CAA GTG GGC AG -3' (reverse); osteocalcin, 5'- TCT TTC TGC TCA CTC TGC TG-3' (forward) and 5'- CAG AGT TTG GCT TTA GGG CA-3' (reverse); osterix, 5'- AAT AGT GGG CAA CTG GAG GG -3' (forward) and 5'GAA CAG AGC AGG CAG GTG AA -3' (reverse); Actin, 5'- CGA TGC CCT GAG GCT CTT TT-3' (forward) and 5'- GGG CCG GAC TCA TCG TAC TC-3' (reverse).

\section{Western blot analysis}

Western blotting was conducted following a standard procedure. Briefly, $\mathrm{C} 2 \mathrm{C} 12$ cells were disrupted in a RIPA lysis buffer $(50 \mathrm{mM}$ Tris; $\mathrm{pH} 8.0,150 \mathrm{mM} \mathrm{NaCl}, 0.5 \%$ sodium deoxycholate, $1.5 \mathrm{mM} \mathrm{MgCl} 2,1 \mathrm{mM}$ EGTA, $1 \%$ Triton X-100, $10 \mathrm{mM} \mathrm{NaF}$, and complete protease inhibitor cocktail). The protein concentrations of cell lysates were determined using a detergent-compatible protein assay kit (Bio-Rad Laboratories, CA, USA), and $30-45 \mu \mathrm{g}$ of total protein was resolved using $8-10 \%$ SDS-polyacrylamide gel electrophoresis. Separated proteins 

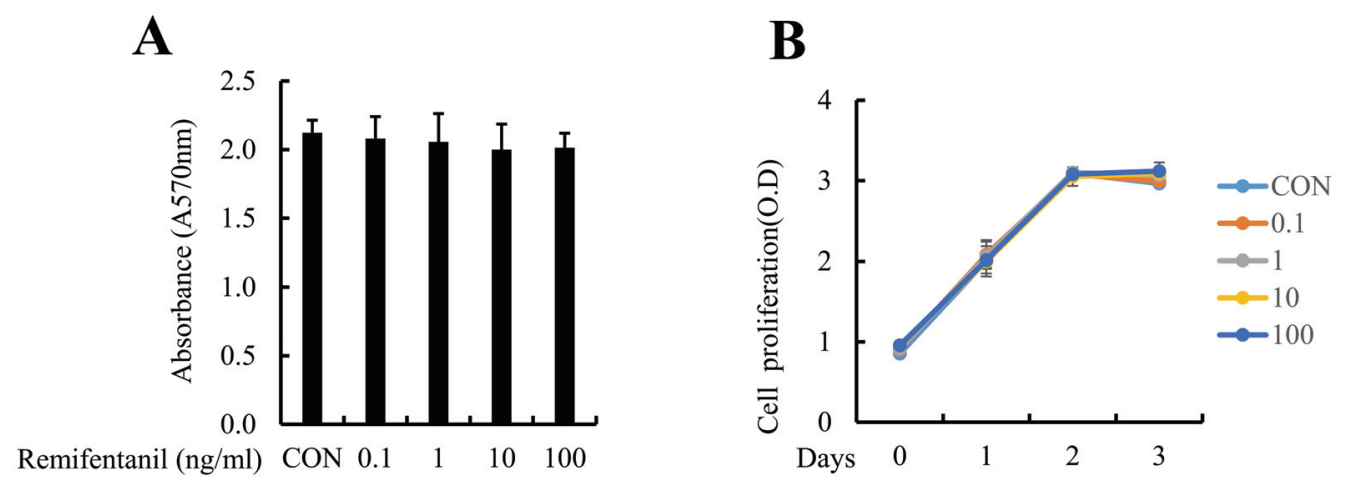

Fig. 1. Effect of remifentanil on cytotoxicity and cell proliferation in $\mathrm{C} 2 \mathrm{C} 12$ cells. (A) C2C12 cells were incubated in medium containing indicated concentrations of remifentanil $(0-100 \mathrm{ng} / \mathrm{ml})$ for $24 \mathrm{~h}$. Cell viability was evaluated by MTT assay. (B) C2C12 cells were cultured in DMEM and 100 $\mu \mathrm{g}$ of BMP-2 for 3 days in the presence of indicated doses of remifentanil $(0-100 \mathrm{ng} / \mathrm{ml})$. Cell proliferation was measured at daily intervals by MTT assay. CON: control

were transferred onto nitrocellulose membranes, and the membranes were blocked with $5 \%$ skim milk for $1 \mathrm{~h}$. After incubation with appropriate primary/secondary antibodies, the immunoreactivity of the membranes was visualized with enhanced chemiluminescence (Amersham Pharmacia Biotech, Buckinghamshire, United Kingdom).

\section{Statistical analysis}

Data are presented as the mean \pm standard deviation (SD) of results from three independent experiments. The Student's t-test was used to determine the significance of differences between two groups. Differences with a $\mathrm{p}$ value $<0.05$ were regarded as being statistically significant and denoted using an asterisk.

\section{RESULTS}

\section{Remifentanil did not exert cytotoxic effects or alter cell proliferation in $\mathrm{C} 2 \mathrm{C} 12$ cells}

The effect of remifentanil on the cell viability of $\mathrm{C} 2 \mathrm{C} 12$ cells was examined using the MTT assay. As shown in Fig. 1A, the MTT assay results indicated that the viability of $\mathrm{C} 2 \mathrm{C} 12$ cells was not affected by various concentrations of remifentanil $(0-100 \mathrm{ng} / \mathrm{ml})$. The proliferation of $\mathrm{C} 2 \mathrm{C} 12$ cells increased with time, but there were no significant differences observed with increasing doses of remifentanil (Fig. 1B).

\section{Remifentanil increased osteoblast differentiation of preosteoblastic $\mathrm{C}_{2} \mathrm{C} 12$ cells}

To examine the role of remifentanil in osteoblast differentiation, $\mathrm{C} 2 \mathrm{C} 12$ cells were cultured in osteogenic media containing BMP-2 and treated with remifentanil $(0,1$, and $10 \mathrm{ng} / \mathrm{ml})$. After 24 and $72 \mathrm{~h}$, the cultured $\mathrm{C} 2 \mathrm{C} 12$ cells were stained for ALP. As shown in Fig. 2A and $\mathrm{B}, 10 \mathrm{ng} / \mathrm{ml}$ of remifentanil significantly increased ALP staining and the ALP-positive area of $\mathrm{C} 2 \mathrm{C} 12$ cells compared to BMP-2 group (Fig. 2A, B). This result shows that remifentanil promoted osteoblast differentiation in the preosteoblastic $\mathrm{C} 2 \mathrm{C} 12$ cells.

\section{Remifentanil increased cell migration of $\mathrm{C} 2 \mathrm{C} 12$ cells in the Boyden chamber migration assay}

The migration of $\mathrm{C} 2 \mathrm{C} 12$ cells was evaluated using the Boyden chamber migration assay. As shown in Fig. 3A, remifentanil increased migration of $\mathrm{C} 2 \mathrm{C} 12$ cells compared to control. In addition, migrated cell numbers were significantly increased after transfection with 10 and 50 $\mathrm{ng} / \mathrm{ml}$ of remifentanil compared to the control (Fig. 3B).

\section{Remifentanil upregulated the expression of Runx2 and osterix}

We demonstrated that remifentanil increased osteoblast differentiation (Fig. 2). To establish the mechanism involved in the effect of remifentanil on osteoblast 


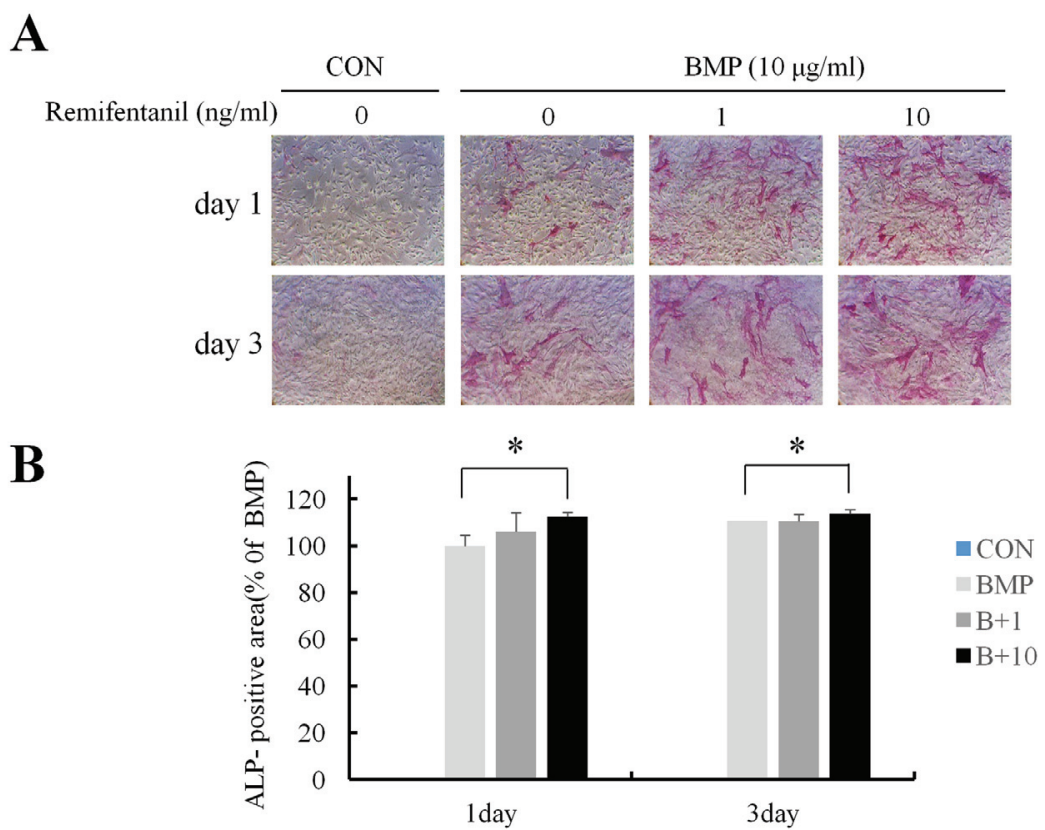

Fig. 2. Effect of remifentanil on osteoblast differentiation in preosteoblastic C2C12 cells. (A) C2C12 cells were cultured in osteogenic media (DMEM and $100 \mu \mathrm{g} / \mathrm{ml} \mathrm{BMP-2}$ ) for the indicated number of days. The cells were treated with remifentanil $(0,1 \mathrm{and} 10 \mathrm{ng} / \mathrm{ml})$. At day 1 and day 3, osteoblast differentiation was examined by alkaline phosphatase (ALP) staining. (B) ALP-positive area of C2C12 cells was quantified by densitometry of triplicate experiments. All quantitative data are means \pm SD of three independent experiments ( ${ }^{*}, \mathrm{P}<0.05$ ). CON: control; BMP-2: bone morphogenetic protein-2

A
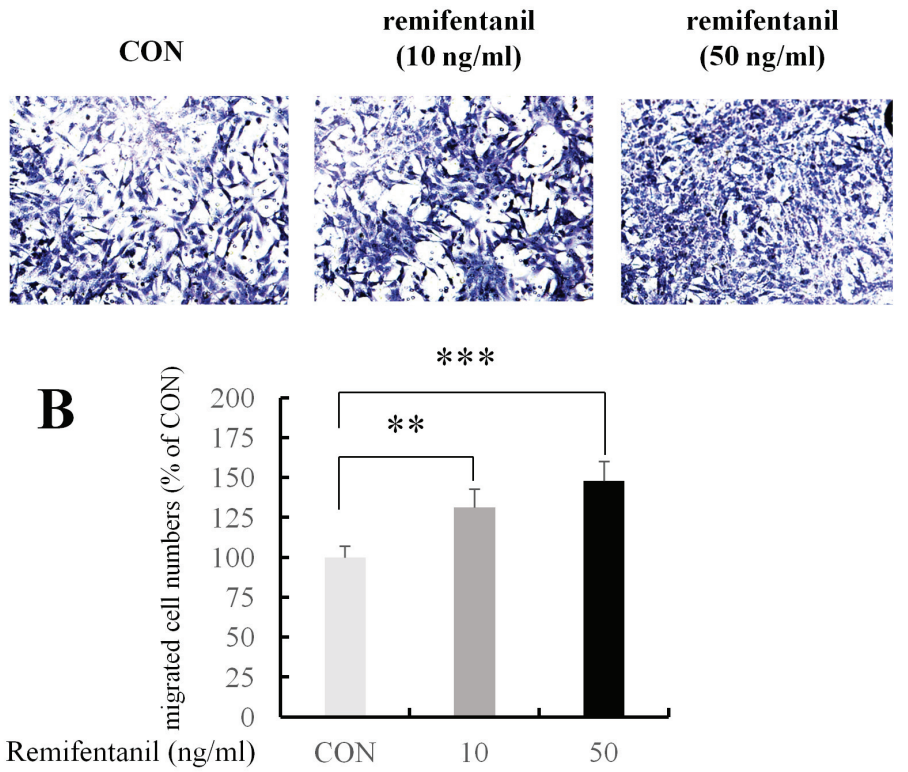

Fig. 3. Cell migration of $\mathrm{C} 2 \mathrm{C} 12$ cell was evaluated using Boyden chamber migration assay. (A) The C2C12 cells in DMEM media were added on the upper chamber and remifentanil $(10$ and $50 \mathrm{ng} / \mathrm{ml})$ in DMEM media was added into the lower chamber. Migrated C2C12 cells in lower chamber were fixed and stained with crystal violet solution. (B) Migrated cell numbers were counted. All quantitative data are means \pm SD of three independent experiments $\left(* *, P<0.01,{ }^{* *}, P<0.001\right)$. CON: control

differentiation, we investigated the mRNA expression of various osteoblastic gene markers (Runx2, OPN, BSP, COL1A1, osteocalcin, and osterix) using RT-PCR. As shown in Fig 4A, remifentanil treatment increased mRNA expression of Runx 2 and osterix in the preosteoblastic $\mathrm{C} 2 \mathrm{C} 12$ cells, compared to that in the BMP-2 group. 
A

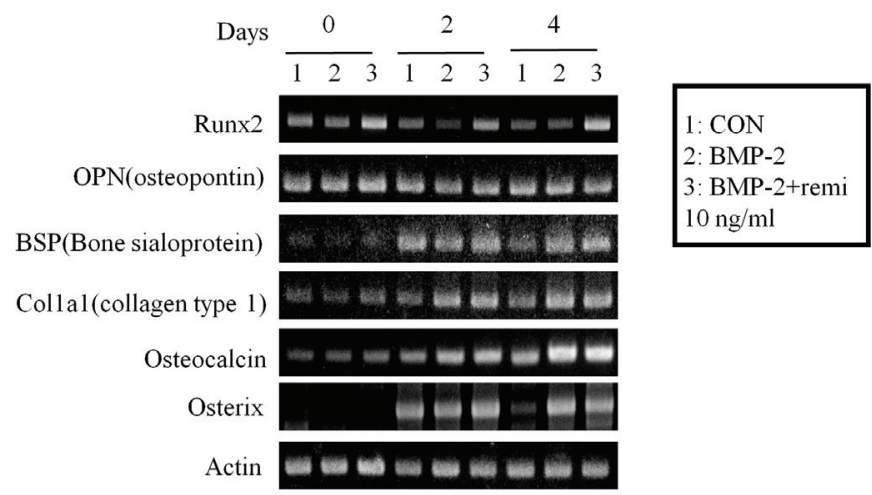

B

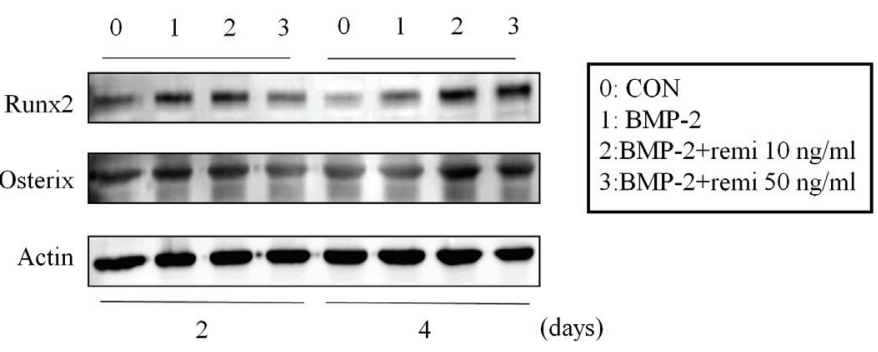

C

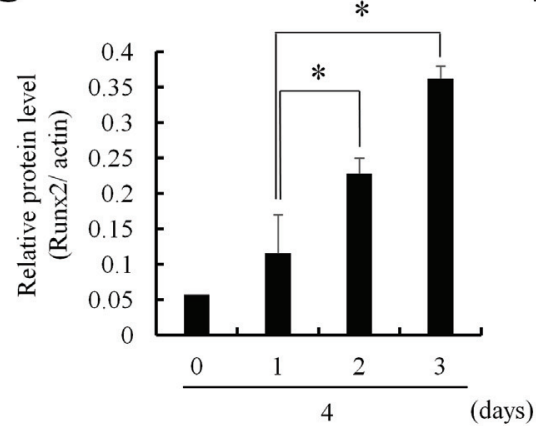

D

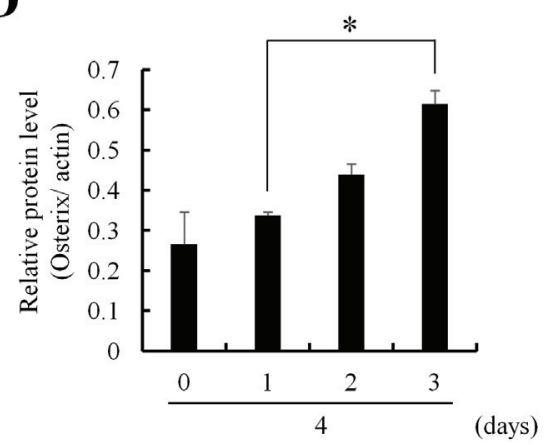

Fig. 4. The expression of Runx2 and osterix was increased by remifentanil. (A) The mRNA expression of various osteoblastic differentiation markers such as Runx2, osteopontin (OPN), bone sialoprotein (BSP), collagen type I (COL1A1), osteocalcin and osterix were evaluated using RT-PCR. (B) Western blot analysis was performed to investigate the expression of Runx2 and osterix. (C, D) The protein level of Runx2 and osterix was quantified. All quantitative data are means \pm SD of three independent experiments $\left(^{*}, \mathrm{P}<0.05\right)$. CON: control; BMP-2: bone morphogenetic protein-2

The protein expression of Runx2 and osterix were evaluated in $\mathrm{C} 2 \mathrm{C} 12$ cells using western blot analysis after remifentanil treatment for 4 days. The protein level of Runx2 significantly increased after treatment with both 10 and $50 \mathrm{ng} / \mathrm{ml}$ of remifentanil, compared to the BMP-2 group (Fig. 4B, C). Remifentanil treatment increased the protein expression of Runx 2 in a dose dependent manner. As shown in Fig. 4D, the protein expression of osterix significantly increased after $50 \mathrm{ng} / \mathrm{ml}$ of remifentanil compared to the BMP-2 group. These results imply that remifentanil promotes osteoblast differentiation in preosteoblastic $\mathrm{C} 2 \mathrm{C} 12$ cells via upregulation of Runx2/ osterix expression.

\section{DISCUSSION}

The primary role of osteoblasts is in the formation of bone. Besides this primary function, osteoblasts have an important role in osteoclast differentiation via cell-cell communication [11]. This communication can occur through direct contact or diffusible paracrine factors, such 
as growth factors, cytokines, chemokines, and other small molecules [12]. Due to their multifunction property, osteoblasts are regarded as critical cells in the overall processes of bone remodeling. We used $\mathrm{C} 2 \mathrm{C} 12$ cells as a preosteoblast to investigate osteoblast differentiation, migration, and proliferation. $\mathrm{C} 2 \mathrm{C} 12$ cells are a mouse pluripotent mesenchymal cell line, which are capable of rapid proliferation and myoblastic differentiation. These cells are commonly used to study the differentiation of myoblasts, osteoblasts, and myogenesis to express various target proteins and to explore mechanistic biochemical pathways in vitro [13]. In our study, $\mathrm{C} 2 \mathrm{C} 12$ cells were suitable for the evaluation of osteoblast differentiation and for studying the expression of various osteoblastic differentiation markers by treatment with BMP-2, which causes a shift from myoblastic differentiation to osteoblastic differentiation in $\mathrm{C} 2 \mathrm{C} 12$ cells.

In the present study, we investigated the effects of remifentanil on osteoblast differentiation by measuring the expression of osteoblast-specific genes under BMP-2 treatment. BMP has a major role in the regulation of osteoblast lineage-specific differentiation and later bone formation [14]. Among the BMPs, BMP-2, 6, and 9 have all been reported to have an important role in the induction of mesenchymal stem cell differentiation into osteoblasts [15]. BMP-2 promotes osteoblastogenesis via two types of serine/threonine kinase receptors: BMP-2 binds to the type II receptor and subsequently activates the type I receptor. Signals from the activated type I receptor are transmitted to the nucleus through the SMAD and mitogen-activated protein kinase (MAPK) pathways, which upregulate the expression of Runx 2 and osterix, and facilitate osteoblast differentiation and bone formation [16]. As shown in Fig. 2, the intensity of ALP staining and the size of the ALP positive area increased after BMP-2 treatment. In addition, the mRNA expression of Runx2, BSP, COL1A1, osteocalcin and osterix were enhanced by BMP-2 treatment. These results support the idea that BMP-2 promotes osteoblastogenesis and are in accord with previous studies.

During bone remodeling, preosteoblasts or their pre- cursors migrate into bone resorption cavities and start to form bone by filling in the bone cavities [17]. Therefore, preosteoblastic cell migration is a critical process in bone remodeling to preserve bone mass [18]. In addition, it is crucial for the repair of bone damage caused by pathologic states, such as osteoporosis and bone fracture. Preosteoblasts and osteoblasts have been reported to migrate toward chemo-attractant, but the key molecules involved in osteoblastic cell migration have not yet been studied [19]. In the present study, we have demonstrated that remifentanil increases cell migration of preosteoblasts, suggesting that remifentanil can contribute to bone healing by inducing preosteoblastic cell migration.

This study has shown that remifentanil increases osteoblastic differentiation by upregulating the expression of two key osteogenic transcription factors, Runx2 and osterix. Runx 2 is an essential transcription factor that gives rise to the osteoblast lineage from mesenchymal stem cells, and once Runx 2 is activated, the cells are defined as pre-osteoblasts in the osteoblast lineage [7]. Osterix is a zinc-finger transcription factor and has been shown to be required for bone formation and mineralization in vivo. In addition, osterix is a known downstream target of Runx2 during osteoblast differentiation [20]. Y. Nishio et al. [21] reported in their study that Runx2 binds to the osterix promoter and leads to the activation of osterix transcriptional regulation. Runx2 and osterix have been reported to interact and cooperatively regulate the expression of bone-specific genes. Therefore, the upregulation of Runx 2 is usually accompanied by the activation of osterix.

In conclusion, remifentanil increased osteoblast differentiation in vitro through the upregulation of Runx2 and osterix expression. In addition, preosteoblastic cell migration was enhanced by remifentanil treatment. Although this study has some limitations with respect to being an in vitro study, and further studies are needed to fully elucidate our findings, it does suggest that remifentanil has the potential for assisting with bone formation and bone healing. 


\section{AUHOR OROIDS}

Ji-Young Yoon: https://orcid.org/0000-0002-9097-0531

Tae-Sung Kim: https://orcid.org/0000-0001-6411-5307

Ji-Hye Ahn: https://orcid.org/0000-0001-8811-8465

Ji-Uk Yoon: https://orcid.org/0000-0002-3971-2502

Hyung-Joon Kim: https://orcid.org/0000-0002-2962-9553

Eun-Jung Kim: https://orcid.org/0000-0003-4982-9517

ACKNOWLEDGEMENTS: This study was supported by 2018 Clinical Research Grant, Pusan National University Dental Hospital.

COMPETING INTERESTS: The authors have declared that no competing interest exists.

\section{REFERENCES}

1. Papachroni KK, Karatzas DN, Papavassiliou KA, Basdra EK, Papavassiliou AG. Mechanotransduction in osteoblast regulation and bone disease. Trends Mol Med 2009; 15: 208-16.

2. Hill PA. Bone remodelling. Br J Orthod 1998; 25: 101-7.

3. Harvey N, Dennison E, Cooper C. Osteoporosis: impact on health and economics. Nat Rev Rheumatol 2010; 6: 99-105.

4. Pittenger MF, Mackay AM, Beck SC, Jaiswal RK, Douglas $\mathrm{R}$, Mosca JD, et al. Multilineage potential of adult human mesenchymal stem cells. Science 1999; 284: 143-7.

5. Jensen ED, Gopalakrishnan R, Westendorf JJ. Regulation of gene expression in osteoblasts. Biofactors 2010; 36: 25-32.

6. Long F. Building strong bones: molecular regulation of the osteoblast lineage. Nat Rev Mol Cell Biol 2011; 13: 27-38.

7. Stein GS, Lian JB, van Wijnen AJ, Stein JL, Montecino $\mathrm{M}$, Javed A, et al. Runx 2 control of organization, assembly and activity of the regulatory machinery for skeletal gene expression. Oncogene 2004; 23: 4315-29.

8. Komatsu R, Turan AM, Orhan-Sungur M, McGuire J, Radke OC, Apfel CC. Remifentanil for general anaesthesia: a systematic review. Anaesthesia 2007; 62: 1266-80.

9. Yoon JY, Kim DW, Kim EJ, Park BS, Yoon JU, Kim
$\mathrm{HJ}$, et al. Protective effects of remifentanil against $\mathrm{H} 2 \mathrm{O} 2-$ induced oxidative stress in human osteoblasts. J Dent Anesth Pain Med 2016; 16: 263-71.

10. Baik SW, Park BS, Kim YH, Kim YD, Kim CH, Yoon JY, et al. Effects of Remifentanil Preconditioning on Osteoblasts under Hypoxia-Reoxygenation Condition. Int J Med Sci 2015; 12: 583-9.

11. Kular J, Tickner J, Chim SM, Xu J. An overview of the regulation of bone remodelling at the cellular level. Clin Biochem 2012; 45: 863-73.

12. Kwan Tat S, Padrines M, Theoleyre S, Heymann D, Fortun Y. IL-6, RANKL, TNF-alpha/IL-1: interrelations in bone resorption pathophysiology. Cytokine Growth Factor Rev 2004; 15: 49-60.

13. Katagiri T, Yamaguchi A, Komaki M, Abe E, Takahashi $\mathrm{N}$, Ikeda $\mathrm{T}$, et al. Bone morphogenetic protein-2 converts the differentiation pathway of $\mathrm{C} 2 \mathrm{C} 12$ myoblasts into the osteoblast lineage. J Cell Biol 1994; 127: 1755-66.

14. Beederman M, Lamplot JD, Nan G, Wang J, Liu X, Yin $\mathrm{L}$, et al. BMP signaling in mesenchymal stem cell differentiation and bone formation. J Biomed Sci Eng 2013; 6: 32-52.

15. Cheng H, Jiang W, Phillips FM, Haydon RC, Peng Y, Zhou L, et al. Osteogenic activity of the fourteen types of human bone morphogenetic proteins (BMPs). J Bone Joint Surg Am 2003; 85-A: 1544-52.

16. Ghosh-Choudhury N, Abboud SL, Nishimura R, Celeste A, Mahimainathan L, Choudhury GG. Requirement of BMP-2-induced phosphatidylinositol 3-kinase and Akt serine/threonine kinase in osteoblast differentiation and Smad-dependent BMP-2 gene transcription. J Biol Chem 2002; 277: 33361-8.

17. Delaisse JM. The reversal phase of the bone-remodeling cycle: cellular prerequisites for coupling resorption and formation. Bonekey Rep 2014; 3: 561.

18. Dirckx N, Van Hul M, Maes C. Osteoblast recruitment to sites of bone formation in skeletal development, homeostasis, and regeneration. Birth Defects Res C Embryo Today 2013; 99: 170-91.

19. Tang Y, Wu X, Lei W, Pang L, Wan C, Shi Z, et al. TGF-beta1-induced migration of bone mesenchymal stem 
cells couples bone resorption with formation. Nat Med 2009; 15: 757-65.

20. Nakashima K, Zhou X, Kunkel G, Zhang Z, Deng JM, Behringer RR, et al. The novel zinc finger-containing transcription factor osterix is required for osteoblast differentiation and bone formation. Cell 2002; 108: 17-29.

21. Nishio Y, Dong Y, Paris M, O'Keefe RJ, Schwarz EM, Drissi H. Runx2-mediated regulation of the zinc finger Osterix/Sp7 gene. Gene 2006; 372: 62-70. 